\title{
Major Salivary Gland Cancer Clinical TNM Finding v8
}

National Cancer Institute

\section{Source}

National Cancer Institute. Major Salivary Gland Cancer Clinical TNM Finding v8. NCI

Thesaurus. Code C132741.

A clinical finding about one or more characteristics of major salivary gland cancer, following the rules of the TNM AJCC v8 classification system. 